\title{
Role of Galectin-9 in Atopic Dermatitis - Is It Mediated Through E Selectin? A Clinical and Immunohistochemical Study
}

This article was published in the following Dove Press journal: Clinical, Cosmetic and Investigational Dermatology

\author{
Azza Gaber Antar Farag (iD) \\ Dalia Rifaat Al-Sharaky ${ }^{2}$ \\ Sawsan Samy Allam ${ }^{3}$ \\ Hesham Nabil Khaled' \\ 'Dermatology, Andrology and STDs \\ Department, Faculty of Medicine, \\ Menoufia University, Shebin EIKom, \\ Egypt; ${ }^{2}$ Pathology Department, Faculty of \\ Medicine, Menoufia University, Shebin \\ ElKom, Egypt; ${ }^{3}$ Dermatology, Ministry of \\ Health, Damanhour, Behera, Egypt
}

Background: Atopic dermatitis (AD) is a recognized T helper (Th)2, allergic, skin disease. Galectin-9 (gal-9) is a member of galectin family. It alters T-cell balance resulting in Th2 polarization. These Th2 cells yield various cytokines that may influence E selectin expression. Therefore, we hypothesized that gal-9 may have an active role in AD and this role could be mediated through E selectin.

Objective: To assess this hypothesis, immunohistochemical expression of gal-9 and E selectin was investigated in skin lesions, from atopic dermatitis patients, and compared.

Methods: Twenty-two atopic dermatitis patients and ten controls were included in this casecontrol study. SCORAD score was used to evaluate atopic dermatitis severity. Biopsies from skin lesions of $\mathrm{AD}$ patients and matched sites of controls were taken and stained immunohistochemically by gal-9 and E selectin polyclonal antibodies.

Results: Compared to controls, atopic dermatitis patients exhibited a significant increased gal-9 H score, percent of expression, cellular localization $(\mathrm{P}<0.001)$ and intensity $(\mathrm{P}=0.04)$ as well as dermal cellular infiltrate $(\mathrm{P}<0.001)$. Also, there were significant elevations in E selectin $\mathrm{H}$ score $(\mathrm{P}=0.002)$, percent of expression $(\mathrm{P}=0.001)$ and cellular localization $(\mathrm{P}<0.001)$ as well as dermal inflammatory infiltrates in $\mathrm{AD}$ cases than controls. In $\mathrm{AD}, 20$ cases showed co expression of both gal-9 and E selectin in the epidermis with insignificant correlation between their $\mathrm{H}$ scores.

Study Limitations: This study only included a small number of studied subjects.

Conclusion: Galectin-9 and E selectin participates independently in atopic dermatitis pathogenesis, that may help in development of new therapeutic agents in atopic dermatitis management program.

Keywords: galectins, E- selectin, atopic dermatitis

\section{Introduction}

Atopic dermatitis (AD) is a known chronic, pruritic inflammatory disease of the skin. It has a relapsing course. ${ }^{1}$ Usually, AD starts in early childhood and may represent the early phase of the so-called "Atopic March," that represents the natural history of atopic manifestations. ${ }^{2}$ Similar to other allergic disorders, the prevalence of $\mathrm{AD}$ is increasing worldwide reaching up to $20 \%$. In childhood, $\mathrm{AD}$ affects nearly 3.2 million children in the United States. ${ }^{3}$

The manifestations of $\mathrm{AD}$ are a result of a complex interaction between environmental factors, susceptibility genes, skin barrier dysfunction, and immunological abnormalities. ${ }^{4}$
Correspondence: Azza Gaber Antar Farag Dermatology, Andrology and STDs, Faculty of Medicine, Menoufia University, Shebin ElKoom, Al Menoufia 325 I I Egypt

$\mathrm{Tel}+201097787204$

$\mathrm{Fax}+202482226454$

Email azzagaber92@yahoo.com 
Galectin-9 (gal-9) is one of the tandem-repeat galectin family. ${ }^{5}$ It has a wide variety of cellular roles, including modulation of cell differentiation, aggregation, adhesion, and cell death. Also, gal-9 has been well characterized as an eosinophilic chemoattractant. ${ }^{6}$ Additionally, it modifies T-cell balance, resulting in polarization of Th2 cells. ${ }^{7}$ Through these functions, gal-9 can alter many physiological and pathological processes including allergy. ${ }^{8}$

It has been shown that gal-9 has a suppressive function in Th1- and Th17-mediated diseases such as experimental autoimmune encephalomyelitis, complex immune-induced arthritis, rheumatoid arthritis, collagen-induced arthritis, nephritis, diabetes, diabetic nephropathy, psoriasis, allergic asthma, contact dermatitis and graft versus host disease. ${ }^{9}$

Endothelial selectin (E selectin) is an adhesion molecule, expressed on the surface of stimulated endothelial cell upon motivation by inflammatory cytokines such as IL-6, IFN- $\gamma$, and TNF- $\alpha$. In association with intercellular adhesion molecule-1 (ICAM-1), E selectin allows adhesion of neutrophils, monocytes and leukocytes on stimulated endothelium in the skin. ${ }^{10}$

In $\mathrm{AD}$, gal-9 prompts apoptosis in Th1 and Th17 cells, consequently, Th2 polarity takes place. ${ }^{7}$ These Th2 cells produce various cytokines including interleukin- 4 and 5 in the eczematized skin. Such cytokines may encouragement the expression of $\mathrm{E}$ selectin either on keratinocytes or endothelial cells. ${ }^{11}$ Therefore, we suggested that the expected role of gal-9 in AD pathogenesis could be mediated through E selectin.

The aim of this study was to shed light on the role of gal-9 in $\mathrm{AD}$ and to investigate if this role is mediated through E selectin or not, through evaluation of their immunohistochemical expressions in involved skin in atopic dermatitis patients compared to controls, in addition to assess if there is a correlation between both or not.

\section{Materials and Methods}

This case-control study included 22 atopic dermatitis patients (4- to 9-years-old) and 10 healthy volunteers, the control group (3- to 10-years-old). They were selected from the Dermatology outpatient clinicat Menoufia University Hospital between May 2016 and February 2017. The study was approved by the Committee of Human Rights in Research at Menoufia University, in accordance with the Helsinki Declaration in 1975 (revised in 2000). The approval number of Research Ethics Committee of this study is 1202/7/4/2016.

Written informed consent was obtained from every participant or from his or her parent before the study initiation. We included patients with atopic dermatitis (newly diagnosed or recurrent cases) from both sexes. The selected patients did not receive any topical (two week) or systemic (1 month) treatment (including glucocorticoids) for atopic dermatitis before joining the study. Any participant having any immune-inflammatory or allergic disorder and/or patients having any skin disease other than atopic dermatitis was excluded from the study.

\section{Methods}

The studied individuals were subjected to the full history and clinical examination. The diagnosis of $\mathrm{AD}$ was made according to the criteria of Hannifin and Rajka. ${ }^{12}$ Assessment of atopic dermatitis severity was done using the scoring atopic dermatitis (SCORAD) score. ${ }^{13}$

Four millimeter punch biopsies were taken under local anesthesia from the affected skin of each patient and the corresponding sites of the control subjects. The specimens were fixed in a $10 \%$ formalin solution and submitted to routine tissue processing to be embedded in paraffin blocks.

From each specimen, sections of $4 \mu \mathrm{m}$ thickness were cut on routine slides for hematoxylin and eosin staining to confirm the diagnosis of atopic dermatitis, while sections for immunestaining were cut on Poly-L-Lysine coated slides (Thermo Fisher Scientific, 168 Third Avenue, Waltham, MA, USA 02451). The protocol used for immunostaining used for immunostaining was streptavidin-biotin amplified system. ${ }^{14}$ In this system, two reagents were utilized. The primary antibodies for both gal-9 and E selectin were polyclonal rabbit antibodies raised against gal-9 (with Cat. \# YPA1547) and E selectin (with Cat. \# YPA1378). They were received as concentrated $0.1 \mathrm{~mL}(1 \mathrm{mg} / \mathrm{mL})$ with dilution titer 1:200, from Chongqing Biospes Co., Ltd, (7F, Bldg B, High-tech Venture Park, \# 107 Erlang Chuangye Rd, Jiulongpo District, Chongqing, 400039 China, www.Biospes.com).

The biotinlated secondary anti-immunoglobulin is a purified bovine monoclonal anti-mouse IgG (Thermo scientific, NOS-3F7-B11 B5) is capable of binding to the primary antibody and the streptavidin-biotin enzyme complex. Finally, the reaction was visualized by an appropriate substrate/chromogen (Diaminoben-zidine, DAB) reagent (Thermo Fischer scientific catalog number 36,000 Pierce Peroxidase IHC Detection Kit; Thermo Fisher Scientific, 168 Third Avenue, Waltham, MA, USA 02451). Negative control tissue was done by omitting the application of the primary antibody from the stained tissue. Ultra $\mathrm{V}$ block was applied, and slides were incubated for 5 mins in humidity chamber, to block non-specific background staining. 


\section{Immunohistochemical Evaluation}

The sections were deparaffinized in xylene overnight then using two changes, 5 mins then re-hydrated by immersion in descending grades of ethanol (Absolute [100\%] ethanol for $10 \mathrm{mins}$, $95 \%$ ethanol for $10 \mathrm{mins}, 70 \%$ ethanol for 10 mins, and finally in distilled water for 10 mins).

Then the slides were washed in phosphate buffer saline (PBS) twice, for 5 mins each. Excess liquid was dried by absorbent paper then transferred to humidity chamber.

To reduce non-specific background staining due to endogenous peroxidase, the section was incubated in hydrogen peroxide $\left(3 \% \mathrm{H}_{2} \mathrm{O}_{2}\right.$ in absolute methyl alcohol) incubate for 7-10 mins at room temperature. Then the slides were rinsed in PBS twice, 5 mins for each.

For antigen retrieval: Heat induced epitope retrieval (HIER) procedure was done. The slides were put in a slide rack and put in Pyrex container, which contain $500 \mathrm{~mL}$ of citrate buffer. The Pyrex container was then put on a hot plate and the solution was kept boiling for 10-20 mins, then removed and allowed to cool at room temperature, for 20 mins. The slides were rinsed in PBS for two changes and transferred to humidity chamber. Ultra V block was applied, and slides were incubated for 5 mins in humidity chamber, to block non-specific background staining. Excess fluid was removed by shaking the slides gently and step no. 4 was repeated.

Application of the primary antibody; one slide tissue sections is then incubated with gal-9 and the other with e selectin, horizontally in a humidity chamber over-night, at room temperature. Negative control slides were prepared, by omitting the primary antibody from the staining procedure. Tissue sections prepared from human colon was used as a positive control for gal-9, while tissue sections from Human esophagus and lung cancer was used as a positive control for e selectin. Excess reagent was thrown off and slides were rinsed two times in PBS, 5 mins for each then transfer slides to humidity chamber.

Application of secondary antibody; after blotting of excess buffer, 1-2 drops of biotinylated Goat-polyvalent secondary antibody were applied, incubated for $10 \mathrm{mins}$ at room temperature at humidity chamber. Sections then rinsed in PBS two times as before and transfer slides to humidity chamber again. After blotting of excess buffer, 1-2 drops of pre-formed streptavidin peroxides was applied and incubated for $10 \mathrm{mins}$ at room temperature in humidity chamber.

Sections then rinsed in PBS as before and transfer slides to humidity chamber. One or two drops of the prepared substrate- chromogen were applied to the slides for 1-10 mins, depending on the desired stain intensity, guided microscopically. Excess reagent was removed, then, the slides were washed in distilled water.

Counter stain was done using Mayer's Hematoxylin (Bio Genex, cat. No. 94583) for 30-60 seconds to stain nuclei. Sections were washed in tap water for 5 mins. Dehydration of the tissues was, done in ascending grades of ethanol, $70 \%, 90 \%, 100 \%$ ethanol, five minutes for each, and finally cleared in xylene twice.

Gal-9 an E selectin immunohistochemical expressions were confirmed by cytoplasmic and/or nuclear staining as provided by the supplied company. Both gal- 9 and E selectin were evaluated in epidermis for; expression (positive or negative), cellular localization (nuclear and/or cytoplasmic), percentage of positive cells was assessed at $200 \times$ magnification, ${ }^{15}$ intensity of the stain (mild, moderate or strong), and Histo-score (H score): ( $\mathrm{H}$ score $=1 \times \%$ of mildly stained cells $+2 \times \%$ moderately stained cells $+3 \times \%$ of strongly stained cells). ${ }^{16}$ The scoring procedure was done twice by one pathologist and on two different occasions, then the averaged of each score was calculated. The inflammatory cells in the dermis were assessed for expression of both gal-9 and E selectin expression (positive or negative).

\section{Statistical Analysis of Data}

Data were collected, tabulated and statistically analyzed using a personal computer with Statistical Package for Social Science (SPSS) version 15 program (SPSS Inc., Chicago, USA).Qualitative data was expressed as: number and percentage, while, quantitative data was expressed as: arithmetic mean $(\overline{\mathrm{X}})$, median, range standard deviation $(\mathrm{SD})$, and percentage (\%). For comparing qualitative variables, we used Chi- square test $\left(\mathrm{X}^{2}\right.$ - test) and Fisher's exacts test. For comparison between non-normally distributed quantitative variables we used Mann-Whitney $U$-test ( $U$-test). Kruskal-Wallis test $(K$-test) was used in comparing three or more variables. Additionally, Spearman correlations were used for presenting correlation coefficients between gal-9 $\mathrm{H}$ score and selected variables. $\mathrm{P} \leq 0.05$ was considered statistically significant.

\section{Demographic and Clinical Data of Studied Subjects}

Studied AD patients ranged in age from 4 to 9 years. They were 6 males and 16 females. Positive family history was observed in $12(54.5 \%)$ cases. Their disease duration ranged from 1 to 5 years, and the mean age of disease at onset was 
4.3 years. SCORAD score ranged between 20 and 103 . Both $\mathrm{AD}$ patient group and their controls were comparable regarding their age $(\mathrm{p}=0.44)$ and $\operatorname{sex}(\mathrm{p}=0.21)($ Table 1$)$.

\section{Galectin-9 Immune-Reactivity of the Studied Groups}

In control group, gal-9 immune-reactivity was positive in 9 controls $(90 \%)$ showing cytoplasmic localization and mild expression in most of them $(8,88.9 \%)$. Additionally, no gal-9 expression in the dermal elements was observed (Figure 1A).

In atopic dermatitis cases, gal-9 immune-reactivity was positive in all studied cases (22 [100\%]) demonstrating nucleo-cytoplasmic localization in most of them (1777.3\%), with variable intensity (mild in 9 cases [40.9\%], moderate in

Table I Demographic and Clinical Data of Studied Subjects

\begin{tabular}{|c|c|c|c|c|c|c|}
\hline \multirow[t]{2}{*}{ Data } & \multicolumn{2}{|c|}{$\begin{array}{l}\text { Cases } \\
\text { No }=22\end{array}$} & \multicolumn{2}{|c|}{$\begin{array}{l}\text { Control } \\
\text { No }=10\end{array}$} & \multirow[t]{2}{*}{$\begin{array}{l}\text { Test of } \\
\text { Sig. }\end{array}$} & \\
\hline & No & $\%$ & No & $\%$ & & \\
\hline $\begin{array}{l}\text { Age (years) } \\
\text { Mean } \pm \text { SD } \\
\text { Range } \\
\text { Median }\end{array}$ & \multicolumn{2}{|c|}{$\begin{array}{l}6.18 \pm 1.68 \\
4-9 \\
6\end{array}$} & \multicolumn{2}{|c|}{$\begin{array}{l}5.70 \pm 1.56 \\
3-10 \\
5\end{array}$} & $\begin{array}{l}\mathbf{T} \\
0.76\end{array}$ & 0.44 \\
\hline $\begin{array}{l}\text { Sex } \\
\qquad \text { Male } \\
\text { Female }\end{array}$ & $\begin{array}{l}6 \\
16\end{array}$ & $\begin{array}{l}27.3 \\
72.7\end{array}$ & $\begin{array}{l}5 \\
5\end{array}$ & $\begin{array}{l}50 \\
50\end{array}$ & $\begin{array}{l}\text { FXT } \\
1.5\end{array}$ & 0.21 \\
\hline $\begin{array}{l}\text { Duration of disease } \\
\text { Mean } \pm \text { SD } \\
\text { Range } \\
\text { Median }\end{array}$ & \multicolumn{2}{|c|}{$\begin{array}{l}2.42 \pm I .18 \\
I-5 \\
2\end{array}$} & \multicolumn{2}{|c|}{$\longrightarrow$} & & \\
\hline $\begin{array}{l}\text { Age of disease onset } \\
\text { Mean } \pm \text { SD } \\
\text { Range } \\
\text { Median }\end{array}$ & \multicolumn{2}{|c|}{$\begin{array}{l}4.3 \pm 1.2 \\
3-7 \\
4\end{array}$} & \multicolumn{2}{|c|}{$\longrightarrow$} & & \\
\hline $\begin{array}{l}\text { SCORAD Score } \\
\text { Mean } \pm \text { SD } \\
\text { Range }\end{array}$ & \multicolumn{2}{|c|}{$\begin{array}{l}57.3 \pm 28.1 \\
20-103 \\
45\end{array}$} & \multicolumn{2}{|c|}{-} & & \\
\hline $\begin{array}{l}\text { Disease severity } \\
\text { Mild } \\
\text { Moderate } \\
\text { Severe }\end{array}$ & \multicolumn{2}{|c|}{$\begin{array}{l}3(14.3 \%) \\
9(42.9 \%) \\
9(42.9 \%)\end{array}$} & \multicolumn{2}{|c|}{ 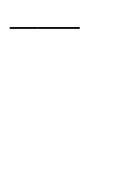 } & & \\
\hline $\begin{array}{l}\text { Family history of } \\
\text { atopic disease } \\
\text { Positive } \\
\text { Negative }\end{array}$ & \multicolumn{2}{|c|}{$\begin{array}{l}12(54.5 \%) \\
10(45.5 \%)\end{array}$} & \multicolumn{2}{|c|}{$\longrightarrow$} & & \\
\hline
\end{tabular}

Note: T: Student's $t$-test.

Abbreviation: FXT, Fisher's exact test.
10 patients [45.5\%] and strong in 3 [13.6\%] cases). Concerning inflammatory dermal infiltrate, 19 (86.4\%) cases displayed positive gal-9 (Figure 1B and C).

Compared to controls, atopic dermatitis patients exhibited a significant increased gal-9 $\mathrm{H}$ score, percent of expression, cellular localization ( $\mathrm{P}<0.001$ for all), intensity $(\mathrm{P}=0.04)$ and gal-9 expression in dermal cellular infiltrate $(\mathrm{P}<0.001)$ (Table 2).

\section{E Selectin Immune Reactivity of the Studied Subjects}

In control group, E selectin immune-reactivity was positive and showed cytoplasmic localization in 9 control sections (90\%), demonstrating mild expression in 5 $(55.6 \%)$ slides, moderate in $3(33.3 \%)$ and strong in 1 (11.1\%) section, with negative $\mathrm{E}$ selectin expression in dermal cellular elements (Figure 2A).

In atopic dermatitis patient group, E selectin immune reactivity was positive in $21(95.5 \%)$ cases demonstrating nucleocytoplasmic localization in $14(66.7 \%)$ cases and showed mild intensity in 9 (42.9\%). 17 cases $(81 \%)$ had positive E selectin immune reactivity in dermal inflammatory cells (Figure 2B and C).

There were significant elevations in $\mathrm{H}$ score of $\mathrm{E}$ selectin immune-reactivity $(\mathrm{P}=0.002)$, it's percent of expression $(\mathrm{P}=0.001)$ and cellular localization $(\mathrm{P}<0.001)$ in $\mathrm{AD}$ cases than controls. Also, in AD cases, E selectin immune reactivity in dermal inflammatory infiltrates was significantly expressed than controls ( $81 \%$ versus 0 ) (Table 3 ).

\section{The Relation Between Gal-9 and E Selectin in Atopic Patients}

Twenty out of 22 studied atopic dermatitis cases showed co expression of both gal-9 and E selectin. The epidermis is the part of skin that showed the co expression (Figure 3). There was a non-significant negative correlation between gal-9 and E selectin $\mathrm{H}$ scores in the investigated $\mathrm{AD}$ patients $(\mathrm{r}=-0.03$, $\mathrm{P}=0.86$ ) (Table 4).

\section{The Relation Between Gal-9 and Studied Parameters in AD Patients}

There was a significant positive correlation between gal-9 $\mathrm{H}$ score and SCORAD score of the studied AD cases $(\mathrm{P}<0.001)$ (Table 4).

\section{Discussion}

In normal situation, gal-9 is expressed by cutaneous Langerhans cells and peripheral myeloid DCs. ${ }^{17}$ In line 


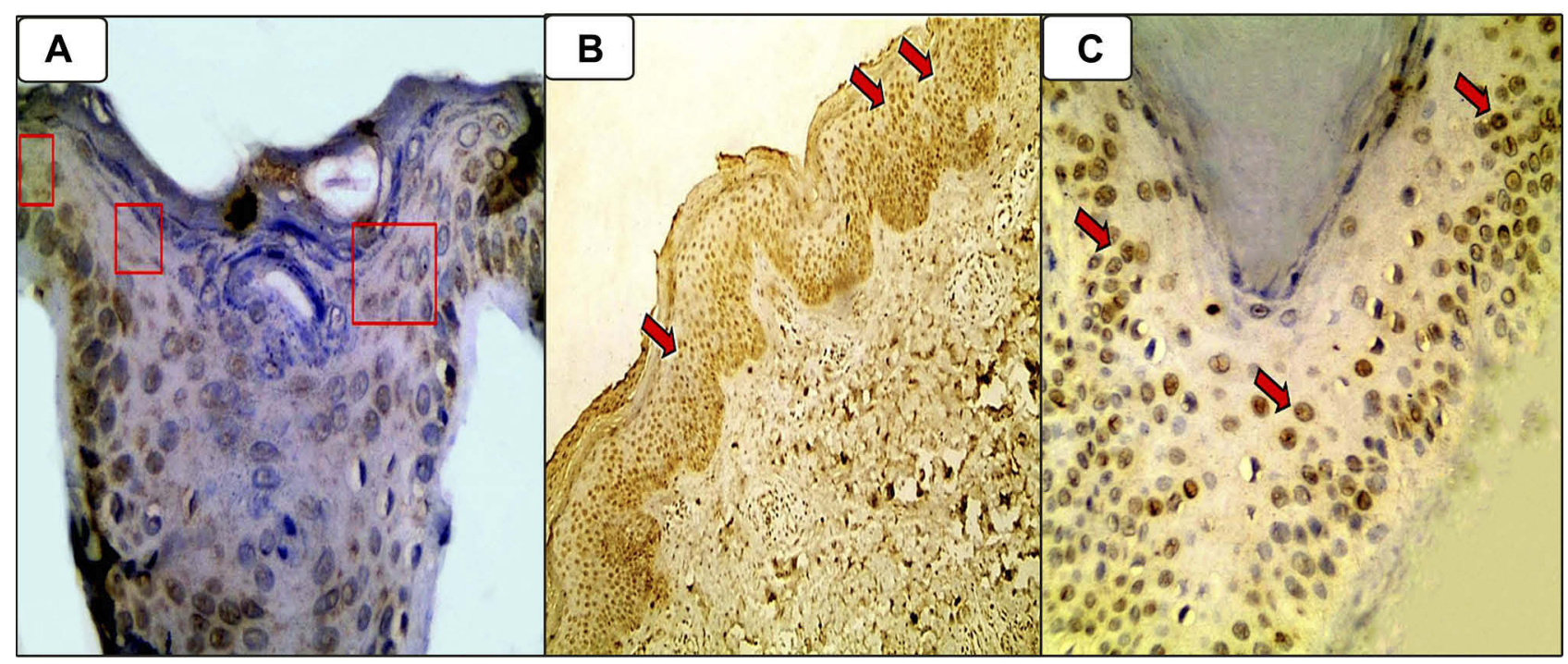

Figure I (A) Patchy mild cytoplasmic expression of gal-9 (red boxes) in control epidermis (Immunoperoxidase, $400 \times$ ); (B) Diffuse moderately nucleo-cytoplasmic expression (red arrows) of gal-9 is in epidermal keratinocytes in AD skin section (Immunoperoxidase, $40 \times$ ); (C) Mild nuclear expression (red arrows) of gal-9 in the epidermal keratinocytes of AD skin section (Immunoperoxidase, $400 \times$ ).

with this observation, the current study, revealed that gal-9 immune-reactivity was positive in most studied control sections and was mainly of mild intensity. Recombinant gal-9 was revealed to stimulate maturation of human monocyte derived dendritic cells (DCs). In addition, gal-9 treated DCs release IL-12 and augment the production of Th1 cytokines by allogeneic CD4p T cells. Consequently, gal-9 can encourage DC maturation and support Th1 immune responses that appeared to possess immune-protected properties. ${ }^{18}$

In $\mathrm{AD}$, a recognized Th2 disease, gal-9 adjusts T-cell balance through negatively regulating Th17 as well as Th1 cells, resulting in Th2 polarization. ${ }^{7}$ Additionally, gal-9 is an eosinophilic chemo-attractant protein. ${ }^{6}$ By these regulating functions, increased gal-9 in AD could participate in pathogenesis of $\mathrm{AD}$, and its inhibition may help in improvement the diseases course in those patients. ${ }^{19}$ Moreover, it was reported that gal-9 participates in the development of a number of allergic disorders including asthma $^{20,21}$ and food allergy. ${ }^{8}$

Confirming its role in AD patients, we observed gal-9 immune-reactivity in all studied cases that exhibited significant increase in gal-9 $\mathrm{H}$ score, percent of expression and intensity than their matched pears. Also, gal-9 expression in dermal cellular infiltrate was significantly higher in atopic dermatitis cases than controls. In agreement of this result, Nakajima et al ${ }^{19}$ reported that the expression of gal9 on epidermal keratinocytes of $\mathrm{AD}$ patients $(\mathrm{n}=6)$ was stronger than that observed in normal skin $(n=6)$. Therefore, we suggested that one of the main sources of gal-9 in skin lesion of AD was epidermal keratinocytes. Additionally, increased gal-9 tissue expression may have an active role in $\mathrm{AD}$ development. Consistent with our findings, gal-9 expression was significantly observed on epidermal keratinocyte in involved skin of bullous pemphigoid, another Th2 mediated skin disease, and on intestinal epithelial cells in patients having Th2-mediated food allergy. ${ }^{8,22}$

Parallel to our result, Nakajima et al $^{19}$ from Tokyo, investigated serum levels of gal-9 of $36 \mathrm{AD}$ cases and 29 control subjects. They reported that mean serum gal-9 levels were significantly augmented in AD patients than controls. They concluded that elevated galectin-9 expression may exacerbate $\mathrm{AD}$ and that galectin- 9 could be a therapeutic target in $\mathrm{AD}$ patients.

In the current study, there was a significant positive correlation between gal-9 $\mathrm{H}$ score and severity index (SCORAD score) of atopic dermatitis. In accordance with our findings, serum gal-9 levels were significantly correlated with $\mathrm{AD}$ severity, and were decreased after $\mathrm{AD}$ treatment, and this decrease was associated by a noticeable improvement of skin lesions. ${ }^{19}$ Also, in a mouse model of food allergy, blocking of gal-9 resulted in inhibition of the allergic hypersensitivity state. ${ }^{8}$ In this induced food allergy model, mice were sensitized by $0.1 \mathrm{mg}$ ovalbumin (OVA) with $0.1 \mathrm{~mL}$ of alum hydroxide (alum) [group I] and some of them were treated with OVA and alum as well as with anti-gal-9 antibody 30min prior to each exposure to antigen OVA [group II]. While control 
Table 2 Comparison Between Studied Groups Regarding Galectin-9 Immunoreactivity

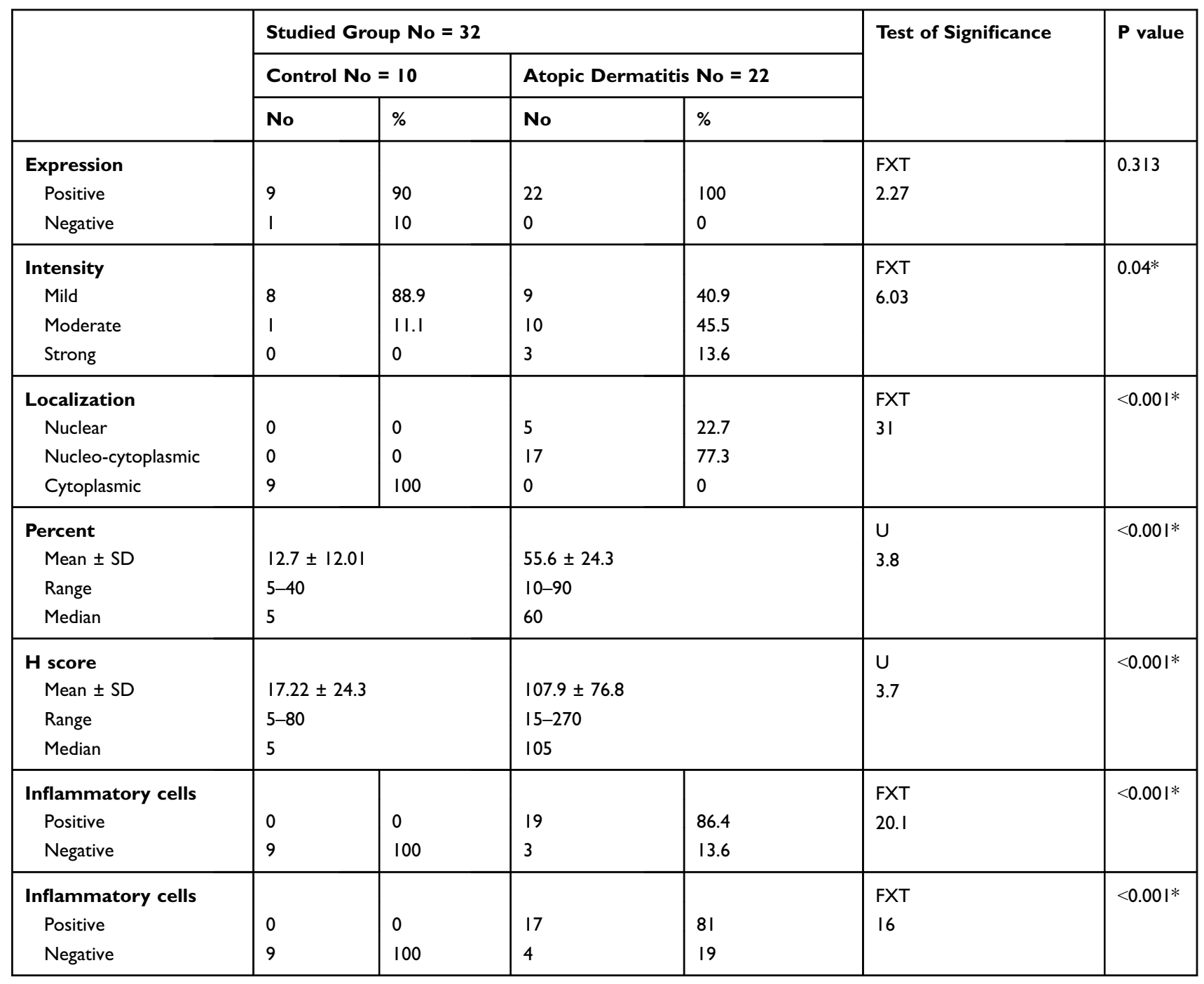

Notes: U: Mann-Whitney U-test. *Statistically significant.

Abbreviation: FXT, Fisher's exact test.

mice were fed with saline. The authors reported that gal-9 contributes to sustaining the allergic status in the intestine [group I], and stalling gal-9 by adding anti gal-9 antibody [group II] inhibited the allergic hypersensitivity status and the antigen-specific Th2 response in the intestine.

Therefore, we may conclude that gal-9 tissue expression not only has an active role in AD development, but also, it participates in its severity, and thus targeting gal-9 may improve the disease course in AD patients.

In the same context, we studied E selectin immune reactivity, that was positive in $90 \%$ of control sections. Supporting this result, Luo et $\mathrm{al}^{23}$ reported that, E selectin is an endothelial-specific linkage molecule that has an important role in leukocyte adhesion. Also, the authors revealed that $\mathrm{E}$ selectin is induced by many inflammatory stimuli as well as non-inflammatory conditions, suggesting that $\mathrm{E}$ selectin is also regulated by growth signals.

Regarding E selectin tissue expression in AD patients, the current study showed that, there were significant elevations in E selectin $\mathrm{H}$ score and it's percent of expression than controls.

In line with these results, Kulisic et $\mathrm{al}^{24}$ on their study on $30 \mathrm{AD}$ patients and 10 controls from Croatia, found that E selectin tissue expression was significantly raised in $\mathrm{AD}$ patients than control group. Additionally, Kagi et $\mathrm{al}^{25}$ and Huang et $\mathrm{al}^{26}$ reported that the level of soluble E selectin was significantly higher in patients having $\mathrm{AD}$ than in healthy control individuals.

The observed up-regulation of $\mathrm{E}$ selectin in involved skin of AD patients could be suggested to be facilitated by 


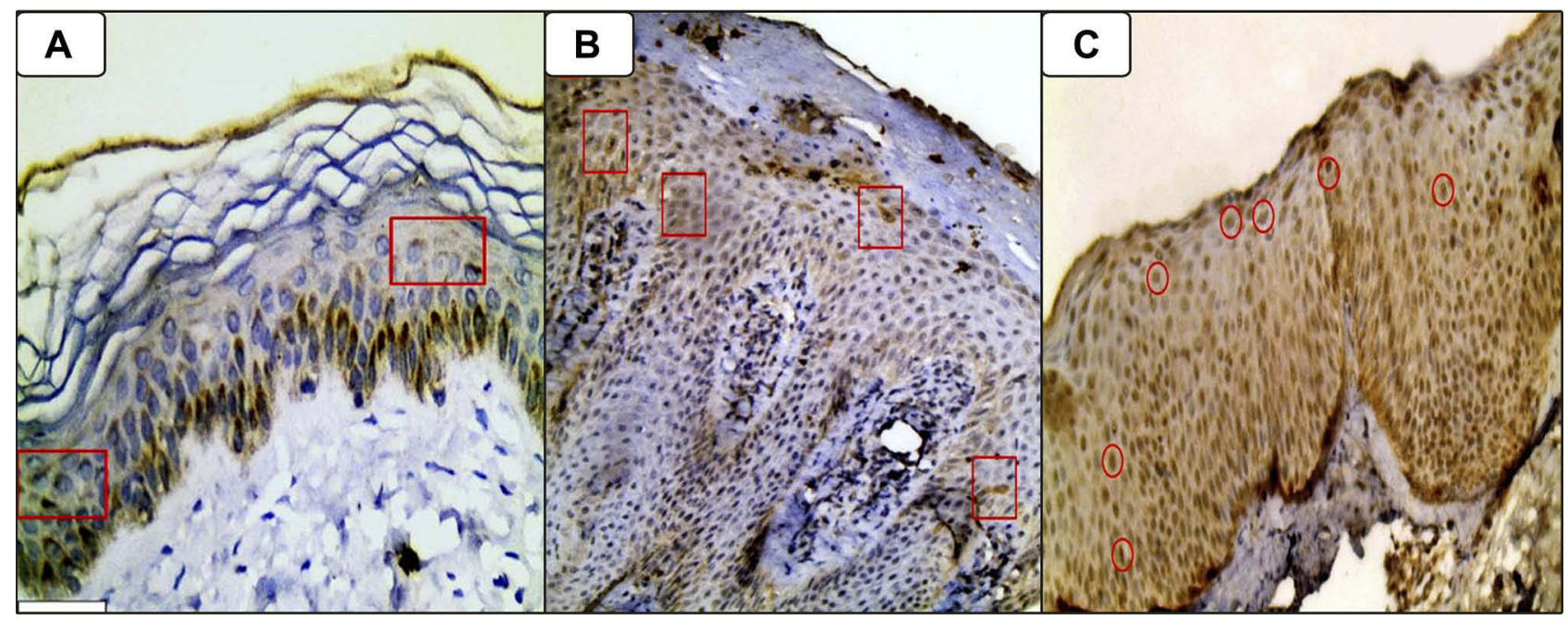

Figure 2 (A) Mild focal cytoplasmic expression of E selectin (red arrows) in epidermal keratinocytes of control section (Immunoperoxidase, $400 \times$ ); (B) Moderate focal cytoplasmic expression of $E$ selectin (red arrows) in AD epidermal keratinocytes (Immunoperoxidase, $200 \times$ ); (C) Diffuse moderate predominantly nuclear expression of E selectin (red circles) in the epidermal keratinocytes of AD skin section (Immunoperoxidase, $400 \times$ ).

some cytokines such as IL-4 that was released from Th2 cells which are dominate in inflammatory process in $\mathrm{AD} .{ }^{27}$ This enhanced tissue $\mathrm{E}$ selectin expression in $\mathrm{AD}$ cases is essential in the interaction with occupying $\mathrm{T}$ lymphocytes in the epidermis and dermis. Accordingly, it may be postulated that the skin of $\mathrm{AD}$ patient provides a special

Table 3 Comparison Between Studied Groups Regarding E Selectin Immunoreactivity

\begin{tabular}{|c|c|c|c|c|c|c|}
\hline & \multicolumn{4}{|c|}{ Studied Group No $=32$} & \multirow[t]{3}{*}{ Test of Significance } & \multirow[t]{3}{*}{$P$ value } \\
\hline & \multicolumn{2}{|c|}{ Control No $=10$} & \multicolumn{2}{|c|}{ Atopic Dermatitis No $=22$} & & \\
\hline & No & $\%$ & no & $\%$ & & \\
\hline Expression & & & & & FXT & 0.56 \\
\hline Positive & 9 & 90 & 21 & 95.5 & 0.34 & \\
\hline Negative & 1 & 10 & I & 4.5 & & \\
\hline Percent & \multirow{2}{*}{\multicolumn{2}{|c|}{$277+1301$}} & \multirow{2}{*}{\multicolumn{2}{|c|}{$47.38 \pm 30.3$}} & $U$ & $0.001 *$ \\
\hline Mean \pm SD & & & & & 3.20 & \\
\hline $\begin{array}{l}\text { Range } \\
\text { Median }\end{array}$ & \multicolumn{2}{|c|}{$\begin{array}{l}10-40 \\
30\end{array}$} & \multicolumn{2}{|c|}{$\begin{array}{l}5-90 \\
40\end{array}$} & & \\
\hline H score & \multirow{4}{*}{\multicolumn{2}{|c|}{$\begin{array}{l}46.6 \pm 35.7 \\
10-120 \\
40\end{array}$}} & \multirow{4}{*}{\multicolumn{2}{|c|}{$\begin{array}{l}103.5 \pm 92.6 \\
5-270 \\
80\end{array}$}} & $u$ & $0.002 *$ \\
\hline Mean \pm SD & & & & & 2.96 & \\
\hline Range & & & & & & \\
\hline Median & & & & & & \\
\hline Intensity & no $=9$ & $\%$ & $\mathrm{no}=21$ & $\%$ & FXT & 0.77 \\
\hline Mild & 5 & 55.6 & 9 & 42.9 & 0.29 & \\
\hline Moderate & 3 & 33.3 & 8 & 38.1 & & \\
\hline Strong & I & II.I & 4 & 19 & & \\
\hline Localization & & & & & FXT & $<0.00 I^{*}$ \\
\hline Nuclear & 0 & 0 & 7 & 33.3 & 30 & \\
\hline Nucleo-cytoplasmic & 0 & 0 & 14 & 66.7 & & \\
\hline Cytoplasmic & 9 & 100 & 0 & 0 & & \\
\hline Inflammatory cells & & & & & FXT & $<0.001 *$ \\
\hline Positive & 0 & 0 & 17 & 81 & 16 & \\
\hline Negative & 9 & 100 & 4 & 19 & & \\
\hline
\end{tabular}

Notes: U: Mann-Whitney U-test. *Statistically significant.

Abbreviation: FXT, Fisher's exact test. 


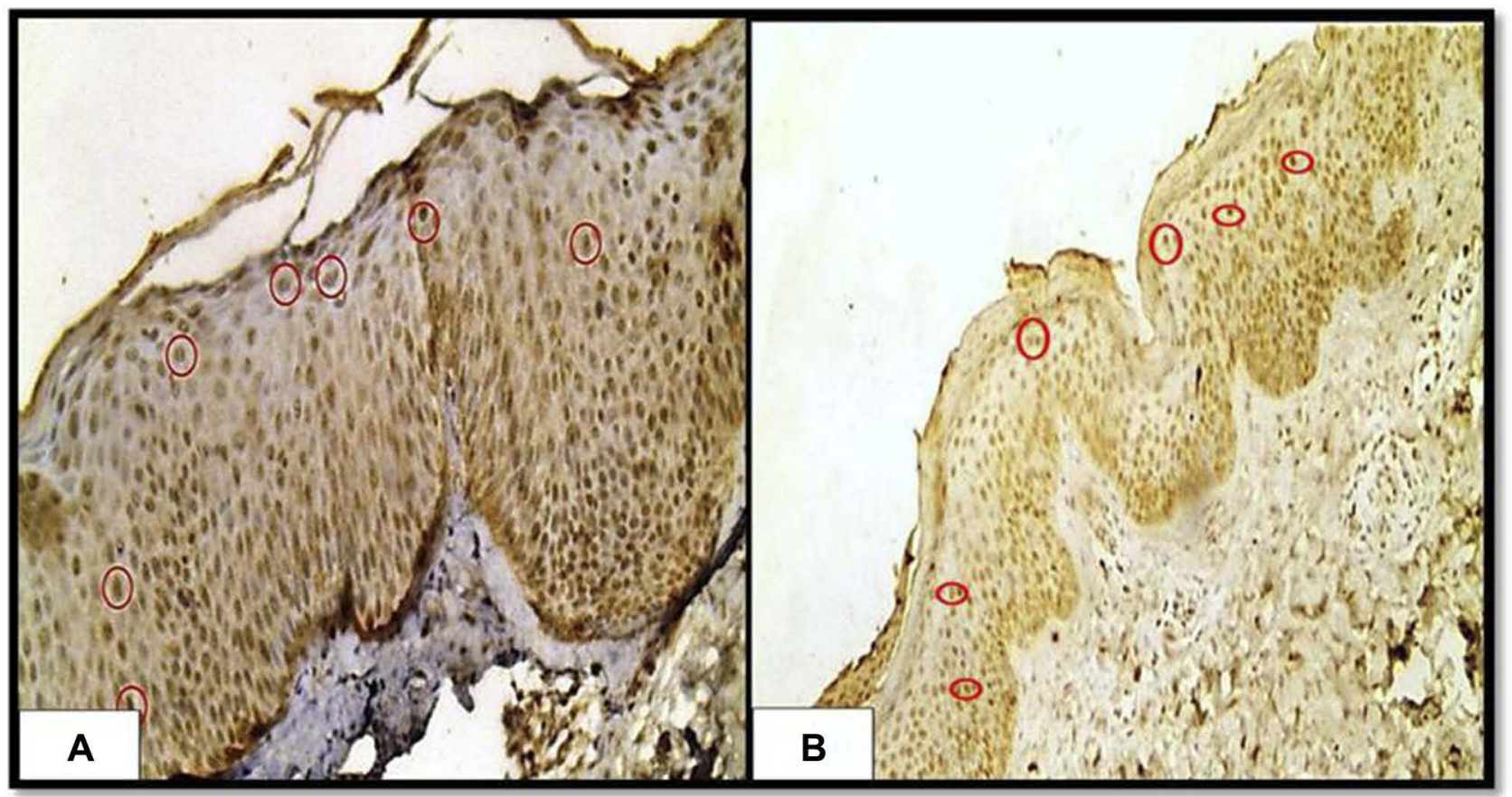

Figure 3 Showing co-localization of the both E-selectin (A) and galectin-9; (B) immunohistochemical nucleo-cytoplasmic expression (red circles in both (A and B) in the epidermis of a case of atopic dermatitis (immunoperoxidase $200 \times \mathrm{HPF}$ [A], $40 \times \mathrm{HPF}$ [B]).

Table 4 Relationship Between Galectin-9 H Score and Studied Parameters

\begin{tabular}{|l|l|l|}
\hline \multirow{2}{*}{} & \multicolumn{2}{|l|}{ Galectin-9 H Score } \\
\cline { 2 - 3 } & $(\mathbf{r})$ & P value \\
\hline Age (years) & 0.04 & 0.86 \\
Age of onset (years) & 0.06 & 0.77 \\
Disease duration/years & 0.03 & 0.86 \\
SCORAD score & 0.79 & $<0.00 I^{*}$ \\
E selectin H score & -0.03 & 0.86 \\
\hline
\end{tabular}

Note: *Statistically significant.

milieu either for homing or for in loco differentiation of Th-2 cells. $^{24}$

Furthermore, in the present study, dermal inflammatory infiltrates demonstrated significant increase in E selectin immune reactivity in AD cases than controls. Supporting this finding, Jung et $\mathrm{al}^{27}$ reported that in AD skin, epidermal keratinocytes release many cytokines that may provide the first signal for the induction of adhesion molecules and concomitant rise in E-selectin expression on dermal cells.

In the current study, although we found co-localization of gal-9 and E selectin in of studied AD cases, we failed to demonstrate a significant correlation between $\mathrm{H}$ score of both. To best of our knowledge, there is no previous studies investigated the relation between gal-9 and
E selectin in atopic dermatitis patients in blood or tissue levels. Therefore, we suggested that role of gal-9 in AD pathogenesis was not mediated through E selectin in diseased skin of AD patients. However, relatively small sample size was the main limitation of the current work. Therefore, we recommend further large-scale studies to validate our findings.

\section{Conclusion}

Galectin-9 and E selectin participates independently in atopic dermatitis pathogenesis. Additionally, gal-9 tissue expression could be a marker of disease severity in AD patient. Moreover, gal-9 and E selectin could be therapeutic targets in $\mathrm{AD}$ management program.

\section{Acknowledgment}

All authors are grateful to administrative and technical staffs at Dermatology Outpatient Clinic, and Pathology Department, Faculty of Medicine, Menoufia University, Egypt, who kindly helped throughout this study.

\section{Disclosure}

The authors report no other conflicts of interest in this work. 


\section{References}

1. Batmaz SB. Simple markers for systemic inflammation in pediatric atopic dermatitis patients. Indian J Dermatol. 2018;63(4):305-310. doi:10.4103/ijd.IJD_427_17

2. Hill DA, Spergel JM. The atopic march: critical evidence and critical relevance. Ann Allergy Asthma Immunol. 2018;120:131-137. doi:10.1016/j.anai.2017.10.037

3. Silverberg JL. Public health burden and epidemiology of atopic dermatitis. Dermatol Clin. 2017;35:283-289. doi:10.1016/j.det.2017.02.002

4. Silverberg JL. Association between atopic dermatitis and other disorders. F1000Res. 2018;12(7):303-309. doi:10.12688/f1000research.12975.1

5. Liang CC, Li CS, Weng IC, et al. Galectin-9 is critical for mucosal adaptive immunity through the T helper 17-IgA axis. Am J Pathol. 2018;188(5):1225-1235. doi:10.1016/j.ajpath.2018.01.017

6. Rosenberg HF, Druey KM. Eosinophils, galectins, and a reason to breathe. Proc Natl Acad Sci U S A. 2016;113(33):9139-9141. doi:10.1073/pnas.1610644113

7. Panda SK, Facchinetti V, Voynova E, et al. Galectin-9 inhibits TLR7-mediated autoimmunity in murine lupus models. $J$ Clin Invest. 2018;128(5):1873-1887. doi:10.1172/JCI97333

8. Chen X, Song CH, Liu ZQ, et al. Intestinal epithelial cells express galectin-9 in patients with food allergy that plays a critical role in sustaining allergic status in mouse intestine. Allergy. 2011;66 (8):1038-1046. doi:10.1111/j.1398-9995.2011.02585.x

9. Chen H, Lo C, Li C, Hsu DK, Li F. Galectins and cutaneous immunity. Dermatologica Sinica. 2012;30(4):121-127. doi:10.1016/ j.dsi.2012.10.002

10. Caproni M, Torchia D, Antiga E, Volpi W, Fabbri P. Expression of adhesion molecules in atopic dermatitis. Clin Exp Dermatol. 2006;31 (6):813-817. doi:10.1111/j.1365-2230.2006.02214.x

11. Ogawa A, Yoshizaki A, Yanaba K, et al. The differential role of L-Selectin and ICAM-1 in Th1-Type and Th2-Type contact hypersensitivity. $J$ Invest Dermatol. 2010;130(6):1558-1570. doi:10.1038/jid.2010.25

12. Hannifin JM, Rajka G. Diagnostic features of atopic dermatitis. Acta Dermatol Venereol Suppl. 1980;92:44-47.

13. Gelmetti C, Colonna C. The value of SCORAD and beyond: towards a standardized evaluation of severity. Allergy. 2004;59(78):61-65. doi:10.1111/j.1398-9995.2004.00651.x

14. Hofmann K, Titus G, Montibeller JA and Finn FM. Avidin binding of carboxyl-substituted biotin and analogues. Biochemistry. 1982;21 (5):978-984.

15. Bahnassy AA, Zekri AR, El-Houssini S, et al. Cyclin A and cyclin D1 as significant prognostic markers in colorectal cancer patients. BMC Gastroenterol. 2004;23:4-22.
16. Smyth JF, Gourley C, Walker G, et al. Antiestrogen therapy is active in selected ovarian cancer cases; the use of letrozole in estrogen receptor-positive patients. Clin Cancer Res. 2007;13(12):3617-3622. doi:10.1158/1078-0432.CCR-06-2878

17. de la Fuente H, Perez-Gala S, Bonay P, et al. Psoriasis in humans is associated with down-regulation of galectins in dendritic cells. J Pathol. 2012;228(2):193-203. doi:10.1002/path.v228.2

18. Dai SY, Nakagawa R, Itoh A, et al. Galectin-9 induces maturation of human monocyte-derived dendritic cells. J Immunol. 2005;175 (5):2974-2981. doi:10.4049/jimmunol.175.5.2974

19. Nakajima R, Miyagaki T, Oka T, et al. Elevated serum galectin -9 levels in patients with atopic dermatitis. J Dermatol. 2015;42 (7):723-726. doi:10.1111/jde.2015.42.issue-7

20. Yamamoto H, Kashio Y, Shoji H, et al. Involvement of galectin-9 in guinea pig allergic airway inflammation. Int Arch Allergy Immunol. 2007;143(1):95-105. doi:10.1159/000101414

21. Sziksz E, Kozma GT, Pállinger E, et al. Galectin -9 in allergic airway inflammation and hyper-responsiveness in mice. Int Arch Allergy Immunol. 2010;151(4):308-317. doi:10.1159/000250439

22. Igawa K, Satoh T, Hirashima M, Yokozeki H. Regulatory mechanisms of galectin-9 and eotaxin-3 synthesis in epidermal keratinocytes: possible involvement of galectin-9 in dermal eosinophilia of Th1-polarized skin inflammation. Allergy. 2006;61(12):1385-1391. doi:10.1111/all.2006.61.issue-12

23. Luo J, Paranya G and Bischoff J. Non inflammatory expression of E selectin is regulated by cell growth. Blood. 1999;93(11):3785-3791. doi:10.1182/blood.V93.11.3785

24. Marinović Kulišić S, Lipozenčić J, Gregorović G, Lacković G, JurićLekić G. Expression of E-selectin in the skin of patients with atopic dermatitis: morphometric study. Acta Dermato Venerol Croat. 2010;18(3):141-145.

25. Kagi MK, Joller-Jemelka H, Wuthrich B. Soluble E-selectin correlates with disease activity in cyclosporin A-treated patients with atopic dermatitis. Allergy. 1999;54:57-63. doi:10.1034/j.1398-9995. 1999.00866.x

26. Huang JL, Lee WY, Chen LC, Kuo ML, Hsieh KH. Changes of serum levels of interleukin-2, intercellular adhesion molecule-1, endothelial leukocyte adhesion molecule- 1 and Th1 and Th2 cell in severe atopic dermatitis after intravenous immunoglobulin therapy. Ann Allergy Asthma Immunol. 2000;84:345-352. doi:10.1016/S10811206(10)62785-8

27. Jung K, Linse F, Pals ST, et al. Adhesion molecules in atopic dermatitis: patch tests elicited by house dust mite. Contact Dermatitis. 1997;37 (4):163-172. doi:10.1111/j.1600-0536.1997.tb00190.x
Clinical, Cosmetic and Investigational Dermatology is an international, peer-reviewed, open access, online journal that focuses on the latest clinical and experimental research in all aspects of skin disease and cosmetic interventions. This journal is indexed on CAS.
The manuscript management system is completely online and includes a very quick and fair peer-review system, which is all easy to use. Visit http://www.dovepress.com/testimonials.php to read real quotes from published authors. 